\title{
Effect of titanium powder on the bond strength of metal heat treatment
}

\author{
Sa-Hak Kim, Wook-Tae Kim²* \\ 'Department of Dental Technology, Kyungdong University, Wonju, Republic of Korea \\ ${ }^{2}$ Department of Dental Technology and Science, College of Health Science, Shin-Han University, Uijeongbu, Republic of Korea
}

Purpose: Ni-Cr alloy does not contain Beryllium, causing the metal compound to form oxides in the furnace but by using Titanium as a chemical catalyst the forming of the oxides can be controlled, and by controlling the impurities formed on the metal surface, the possibility of the $\mathrm{Ni}-\mathrm{Cr}$ alloy bond strength being increased can be analysed. Materials and Methods: Titanium was used as a chemical catalyst in the porcelain for the oxidation of beryllium-free metal ( $\mathrm{Ni}-\mathrm{Cr}$ ) alloy. The T1 group, which does not use Titanium power as a chemical catalyst is a reference model for comparison. The T2 group and T3 group used $10 \mathrm{~g}$ and $20 \mathrm{~g}$ of Titanium power, respectively. They are fabricated to observe the shear bond strength and surface properties. There was no significance when Oneway ANOVA analysis/Tukey Honestly Significant Difference Test was conducted for statistical analysis among groups $(P>0.05)$. Results: Results of measuring the three-point flexural bond strength of the Ni-Cr alloy and thickness of the oxide film. Experiment $\mathrm{T3}$ using $20 \mathrm{~g}$ Titanium chemical catalyst: $39.22 \pm 3.41 \mathrm{MPa}$ and $6.66 \mu \mathrm{m}$, having the highest bond strength and thinness of oxide film. Experiment T2 using $10 \mathrm{~g}$ Titanium chemical catalyst: $34.65 \pm 1.39 \mathrm{MPa}$ and $13.22 \mu \mathrm{m}$. Experiment $\mathrm{T} 1 \mathrm{using}$ no Titanium chemical catalyst: $32.37 \pm 1.91 \mathrm{MPa}$ and $22.22 \mu \mathrm{m}$. Conclusion: The T2 and T3 experiments using Titanium chemical catalyst showed higher bond strength for the $\mathrm{Ni}-\mathrm{Cr}$ alloy and lower thickness of oxide film than experiment $\mathrm{T} 1$, and the titanium catalyst being able to increase bond strength was observed. (J Dent Rehabil Appl Sci 2017;33(2):71-9)

Key words: Beryllium; Titanium; chemical catalyst; oxide film; bond strength

\section{서론}

금속-도재관(Pocelain Fused to Metal Crown, PFM) 에 사용되는 치과용 비귀금속 합금은 코발트-크롬(Co$\mathrm{Cr}$ )합금, 니켈-크롬(Ni-Cr)합금, 티타늄(Ti), 티타늄 합금 (Ti-6Al-4V)이 주로 사용되고 있다. ${ }^{1}$

치과용 금속이 금속-도재관으로 사용되기 위해서는 상 부 도재와 하부 금속 사이에 적절한 결합강도가 가장 중 요하다. ${ }^{2}$ 이에 영향을 미치는 요인은 화학적 결합, 기계적 결합, 압축력에 의한 결합, 분자 간 인력에 관한 결합 등 이 있다. ${ }^{3}$ 그 중 금속산화물과 도재 간의 화학적 결합이 가장 큰 부분을 차지하며, 열처리 중 산소와 친화력이 큰

*Correspondence to: Wook-Tae Kim

Associate Professor, Department of Dental Technology \& Science, College of Health Science, Shin-Han University, 95 Hoam-ro, Uijeongbu, 11644, Republic of Korea

Tel: +82-31-870-3427, Fax: +82-31-870-3429, E-mail: wrdeul@hanmail.net

Received: January 14, 2017/Last Revision: March 19, 2017/Accepted: April 10, 2017
금속이 표면에 금속 산화물을 형성하여 도재와 화학적 결합을 형성하게 된다. ${ }^{4}$

이 중 니켈-크롬 합금은 코발트-크롬 합금보다 주조성 이 좋으나, 니켈과 크롬이 산화처리나 반복 소성 중 주성 분들이 산화되기 쉬워 $\mathrm{NiO}, \mathrm{CrO}$ 가 $\mathrm{NiCrO}_{4}$ 등의 산화 물로 생성되어 빠르고 두꺼운 산화막을 형성하여 적절한 결합강도를 얻는데 어려움이 있다.

반면 니켈-크롬 합금에 베릴륨을 첨가할 경우 $(\mathrm{Ni}-\mathrm{Cr}-$ $\mathrm{Be})$ 합금의 녹는점을 낮추고 기계적 성질 및 주조성을 향 상시키며 $\mathrm{BeO}$ 의 단층 산화막을 형성하여 도재와의 우수 한 결합강도를 보이기 때문에 금속-도재관으로 널리 활 용 되어왔다. ${ }^{5}$ 그러나 니켈 자체가 세포독성, 알러지, 과 
민반응을 유발할 수 있으며, ${ }^{6}$ 기공 과정에서 발생하는 베 릴륨의 분진 및 증기를 흡입할 경우 과민증 및 인체에 독 성을 유발할 수 있는 잠재적 위험성이 보고되고 있다. ${ }^{7}$

1791년에 영국의 윌리엄 그리거(William Gregor)가 검 은 모래(Ilmenite)로부터 하얀색의 금속산화물을 분리하 는 실험에 성공하였고, 1791년에 크래프로드(Klaproth) 가 그 금속 원소의 이름을 티타늄(Titanium)이라고 임시 로 명명한 것이 영구적인 이름이 되었다. 치과용 금속으 로 티타늄은 생체 친화적이며, 타 금속보다 비중이 낮으 면서도 적절한 기계적 강도를 가지기 때문에 임플란트 상부 구조물, 가철성 및 고정성 금속 구조물 등의 치과용 보철물 제작에도 널리 사용되고 있다. ${ }^{8}$ 그러나 티타늄 주 조 시 발생하는 주조체의 과도한 산화막 형성으로 인해 티타늄과 도재 간의 결합력이 저하되어 박리가 일어나므 로 티타늄만으로 금속-도재관을 제작하기에는 많은 개 선점이 필요한 실정이다.

티타늄 도재수복물을 3 년간 관찰한 결과 단일관은 $85 \%$ 의 성공률을, 고정성 국소의치에서는 $59 \%$ 의 성공률 을 보고하였는데 대부분 실패의 원인은 도재의 파절이였 다. Walter 등 ${ }^{10}$ 은 5 년간의 임상적 관찰에서 안전한 도재 결합을 유지하는 비율이 티타늄관에서 $84 \%$, 금속관에서 는 $98 \%$ 이었음을 보고하였다.

환자의 형태와 색에 대한 심미적인 만족도나 margin 의 적합성이 우수하므로 임상에서 티타늄-도재관의 사용 이 적절하다고 보고하였지만, 티타늄과 도재의 결합강도 가 아직 불충분하다는 것을 알려준다. 이러한 티타늄-도 재 수복물의 낮은 결합강도는 도재를 축성하는 동안 과 도한 티타늄 산화물 표면(Ti oxide scale)의 형성이 결정 적인 실패의 주원인으로 임상적인 보고도 아직 희소하나 $\mathrm{Kaus}^{11}$ 는 임상적 관찰에서 귀금속관에 비하여 티타늄관 의 상대적으로 높은 도재 파절율 보고하고 있다.

티타늄-도재 결합과 관련하여 이런 문제를 해결하기 위해서 증가된 온도에서 티타늄 산화물에 나타나는 산소 의 확산을 제한하고 부착성의 산화물 표면을 만들어 도 재가 접착할 수 있도록 티타늄 표면에 다양한 순수 금속 과 세라믹으로 코팅하여 그 표면을 조절하는 방법들이 연구되고 있다.

이와 다른 측면으로 티타늄이 고온에서 타 금속보다 산소와 빠르게 결합하는 특징을 활용하여, 티타늄은 타 분야에서도 활발하게 연구되고 있으며, 환경 친화적으로 공기정화 작용, 유해물질 분해(탈취작용), 오염방지 기 능, 변색방지 기능 및 향균작용 등의 산업분야의 화학적
촉매로 많이 사용되고 있다. ${ }^{12}$ 그러나 소성과정에서 티타 늄 파우더를 이러한 화학적 촉매로 이용하는 연구는 부 족한 실정이다.

따라서 본 연구에서는 베릴륨이 함유되지 않은 금속도재용 $(\mathrm{Ni}-\mathrm{Cr})$ 합금 산화처리 시 도재로 안에 티타늄파 우더를 화학적 촉매로 사용하지 않은 대조군과 화학적 촉매로 사용한 실험군을 도재소성 후, 시편과 도재 사이 의 결합강도를 3점 굽힘 시험(three-point bending test) 을 통해 티타늄 분말이 화학적 촉매제로 도재와의 결합 강도에 미치는 영향을 알아보고자 하였다.

\section{연구 재료 및 방법}

\section{1. 시편준비}

\section{1) 실험재료}

실험재료는 현재 시판되고 있는 베릴륨이 포함되지 않 은 Ni-Cr 합금인 주조용 Verabond 2v (Aalbadent, Fairfield, USA)를 사용했으며, 도재분말은 Super Pocelain Ex-3 (Noritake Co., Nagoya, Japan)를 사용하였다(Table 1, 2).

Table 1. Technical data of alloys used in study

\begin{tabular}{cc}
\hline Alloy & Verabond 2v \\
\hline Type & Base-metal Grade I \\
Composition (\%) & $\mathrm{Ni}(71.85) \mathrm{Cr}(12.6) \mathrm{Mo}(9)$ \\
$\mathrm{Nb}(4.0) \mathrm{Al}(2.5) \mathrm{Si}(0.5)$ \\
Tensile strength, psi (Mpa) & $148000(1021)$ \\
Yield strength, psi (MPa) & $108000(745)$ \\
Elastic modulus, \% & 18 \\
CTE $\left(\times 10^{-6} /{ }^{\circ} \mathrm{C}\right)$ & $14.1\left(25-500^{\circ} \mathrm{C}\right)$ \\
\hline
\end{tabular}

Table 2. Technical data of porcelains used in study

\begin{tabular}{cc}
\hline Porcelain & Noritake Co., Japan (Shade A3) \\
\hline Opaque (Noritake) & Noritake Co., Japan (Shade A3) \\
CTE $\left(\times 10^{-6} /{ }^{\circ} \mathrm{C}\right)$ & $14.1-14.7$ \\
\hline
\end{tabular}




\section{2) 시편제작}

베릴륨이 함유되지 않은 금속-도재용 $(\mathrm{Ni}-\mathrm{Cr})$ 합금 산화 처리 시 도재로 안에 티타늄을 화학적 촉매로 이용하여 결합강도와 계면특성을 관찰하기 위해 티타늄 파우더를 화학적 촉매로 사용하지 않은 T1군을 대조군으로 하고, $10 \mathrm{~g}, 20 \mathrm{~g}$ 티타늄 파우더를 사용한 시편을 T2, T3군으로 분류하여 시편을 제작 하였다(Table 3 ).

측정을 위한 시편 제작은 로스트 왁스 주조법을 적용 하여 $27 \times 3 \times 0.6 \mathrm{~mm}$ 크기의 plastic판을 이용하여 제 작하고, 표면을 연삭하여 $25 \mathrm{~mm} \times 3 \mathrm{~mm} \times 0.5 \mathrm{~mm}$ 의 형상을 갖는 시편을 제작하였다. 각 군당 10 개씩 하여 30 개를 제작하였고, 계면관찰을 위한 시편도 각 군당 1 개씩 하여 3개를 제작하였다.

전용의 CB-30매몰재(Ticonium, Albany, USA)를 이 용하여 제조사가 제시한 방법으로 매몰하였다. 주조는 electric arc를 열원으로 하는 가압/흡입형 방식의 전용 주조기(Rematitan Autocast, Dentaurum Inc., Ispringen, Germany)를 사용하여 시행하였다.

모든 시편은 방사선 사진촬영을 하여 주조체 내부 기 포 유무를 확인하였다.

도재분말이 도포될 면은 주입선을 절단한 주조시편을 ISO9693 규격에 맞게 $25 \times 3 \times 0.5 \mathrm{~mm}$ 크기가 되도록 기공용 카바이드 바와 샌드페이프로 조정하고, 도재 피 개면을 연마하고, 대조군과 실험군 시편들을 세라믹이 융착 될 면에 3bar의 압력으로 $50 \mu \mathrm{m}$ alumina oxide 분 말로 샌드블라스팅을 실시하고, 증기 세척과 아세톤에 넣어 10 분간 초음파 세척을 하였다.

Table 3. Experimental group of this study

\begin{tabular}{ccc}
\hline Code & Titanium powder & Number \\
\hline T1 & $0 \mathrm{~g}$ & 10 \\
T2 & $10 \mathrm{~g}$ & 10 \\
T3 & $20 \mathrm{~g}$ & 10 \\
\hline
\end{tabular}

Degassing처리는 치과용 porcelain 전용 소성로(Touch \& Press, Dentsply, York, USA)에서 $980^{\circ} \mathrm{C}$ 에서 5분간 처 리를 시행하였다(Table 4).

도재는 시편 중앙부에 직경 $5 \mathrm{~mm}$, 높이 $5 \mathrm{~mm}$ 로 축성 하기 위하여 내경이 $4 \times 4 \times 3 \mathrm{~mm}$ 가 되도록 putty로 제 작하고 그 안에 불투명,투명도재를 축성한 후 진동을 주 어 응축하여 제조사 추천의 소성스케줄에 맞추어 소성하 는 방법으로 제작하였다. 소성 후 금속 위의 과잉 된 도재 는 \#1000 SiC paper로 연마하였다.

\section{2. 시험방법}

\section{1) 결합강도 측정}

결합력을 관찰하기 위하여 시편을 고정 장치에 고정 하고 만능시험기(Instron 3366, Instron, Co., Norwood, USA)에서 span length $20 \mathrm{~mm}$ 의 3점 굽힘 시험 장치를 이용하여 측정하였다(Fig. 1). 시편들의 도재 층이 아래로 향하게 놓고, 중앙에서 $1.5 \pm 0.5 \mathrm{~mm} / \mathrm{min}$ 의 속도로 도 재층 한쪽 끝에서 탈락이 일어날 때까지 하중을 가하여 파절시의 순간 최대 하중을 측정하고 도재와 금속간의 결합력을 산출하였다.

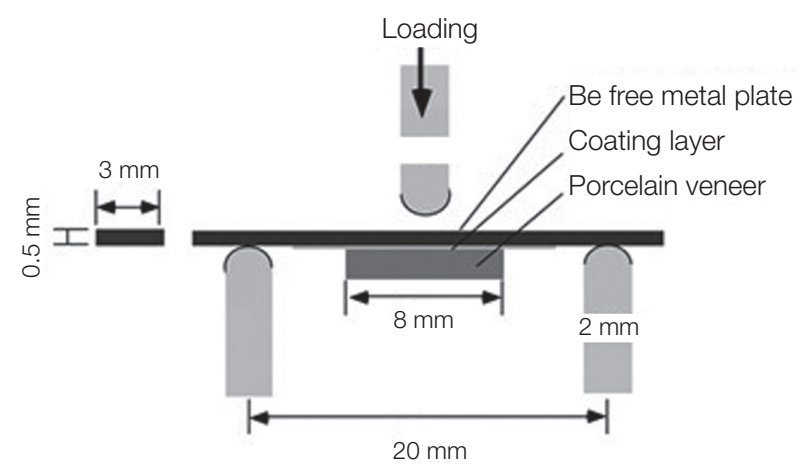

Fig. 1. Specimen and test configuration of ISO 9693 3-point bending test for metal-ceramic bonding strength.

Table 4. Degassing treatment conditions for surface oxidation

\begin{tabular}{cccccccc}
\hline & $\begin{array}{c}\text { Low Temperature } \\
\left({ }^{\circ} \mathrm{C}\right)\end{array}$ & $\begin{array}{c}\text { Preheat Time } \\
(\mathrm{sec})\end{array}$ & $\begin{array}{c}\text { Heat Rate } \\
\left({ }^{\circ} \mathrm{C} / \mathrm{min}\right)\end{array}$ & $\begin{array}{c}\text { Vacuum Level } \\
(\mathrm{cm} / \mathrm{Hg})\end{array}$ & $\begin{array}{c}\text { Vacuum Release High Temperature } \\
\left({ }^{\circ} \mathrm{C}\right)\end{array}$ & $\begin{array}{c}\text { Hold Time } \\
\left({ }^{\circ} \mathrm{C}\right)\end{array}$ & \begin{tabular}{c}
$(\mathrm{min})$ \\
\hline $\mathrm{T} 1, \mathrm{~T} 2, \mathrm{~T} 3$
\end{tabular} \\
\hline
\end{tabular}




\section{2) 시편관찰}

합금과 도재의 결합 계면에 형성된 산화막 두께를 관 찰하기 위해 결합강도 측정 전, 후 단면들을 $\mathrm{Pt}$ 코팅 후 주사 전자현미경(FE-SEM, JSM-7001F, Jeol, Tokyo, Japan)으로 분석하였다.

\section{3) 통계처리}

각 군의 결합강도 결과는 통계적 유의성을 검증하 기 위하여 통계 프로그램(SPSS Statistics 20.0, IBM, Chicago, USA)를 이용하여 분석하였고, 일원배치 분 산분석(one-way ANOVA)은 그룹 간의 차이를 검사 하기 위해서 시행 되었다. 사후 검정(Tukey Honestly Significant Difference test)은 그룹 간의 통계적 차이를 비교하여 시행되었다. 통계적 유의수준은 0.05 로 하였다.

\section{결과}

\section{1. 결합강도 (3점 굴곡시험)}

표면처리에 의한 티타늄 파우더를 화학적 촉매 사용 유무에 따른 결합력을 관찰하기 위하여 3점 굽힘 시험 (three-point bending test)으로 측정하여 결합력을 산출 한 결과, 티타늄 파우더를 화학적 촉매로 $20 \mathrm{~g}$ 사용한 $\mathrm{T} 3$ 군이 $39.22 \pm 3.41 \mathrm{MPa}$ 로 가장 높게 나타났으며, $10 \mathrm{~g}$ 을 사용한 $\mathrm{T} 2$ 군은 $34.65 \pm 1.39 \mathrm{MPa}$, 티타늄 파우더를 화 학적 촉매로 사용하지 않은 대조군 $\mathrm{T} 1$ 군은 $32.37 \pm 1.91$ $\mathrm{MPa}$ 순으로 나타났다(Table 5).

시편들의 결합력의 사후 검정(Tukey test) 결과 실험군 사이에서는 유의성이 있는 차이가 분석되었다 $(P<0.05)$.

도재와 금속 간의 파절 양상은 모두 유사한 형태로 주로 도재와 도재 사이에서 파절이 발생하는 응집실패 (cohesive failure)와 도재와 코핑 사이에 파절이 나타나 는 부착실패(adhesive failure)가 함께 관찰된 혼합실패 양상이 관찰되었으나, T1군에서 부착실패가 나타났고, $\mathrm{T} 2$, T3군의 경우는 응집실패와 부착실패의 양상이 나타 났다.

주사전자현미경 상으로 관찰 된 티타늄 파우더를 화학 적 촉매 이용한 $\mathrm{T} 2, \mathrm{~T} 3$ 군의 경우는 도재 사이에 파절이 일어나 도재가 금속의 표면에 더 많이 부착되어 응집파 절로 혼합실패 양상으로 나타나며, 대조군인 $\mathrm{T} 1$ 군의 경 우는 과도한 산화막으로 접착파절 양상이 두드러진 부 착실패의 양상으로 나타났다.

\section{2. 금속-도재계면 시편분석}

주사전자현미경 상으로 관찰 된 금속계면 SEM사진으 로 산화막 두께를 측정한 결과, T1군은 $23.63 \mu \mathrm{m}, \mathrm{T} 2$ 군 은 $12.38 \mu \mathrm{m}$, T3군은 $6.66 \mu \mathrm{m}$ 으로 측정되었다(Fig. 2).

산화막 두께가 얇은 $\mathrm{T} 3$ 군은 잔존하는 도재가 가장 많 았고, $\mathrm{T} 1$ 군이 가장 적으며 나머지 $\mathrm{T} 2$ 군은 $\mathrm{T} 1$ 군 보다 더 많은 잔존 부위를 보였다.

\section{고찰}

금속-도재관에 사용되는 비귀금속 합금의 사용에 베 릴륨의 유해성으로 첨가되지 않은 금속이 보철물 제작에 사용되고 있다. 국내에서도 베릴륨이 첨가되지 않은 $\mathrm{Ni}-$ $\mathrm{Cr}$ 합금과 생체 안정성이 우수한 $\mathrm{Co}-\mathrm{Cr}$ 합금의 사용만 을 허용하고 있다. ${ }^{13}$ 그래서 산화막 형성이 과다하여 금 속-도재 비귀금속합금의 결합력에 많은 문제점이 발생하 고 있다.

금속-도재관은 금속과 무기재료라는 이종 재료간의

Table 5. Bond strength $(\mathrm{MPa})$ according to surface treatment

\begin{tabular}{cccccccc}
\hline Group & $\mathrm{N}$ & Mean* & $\begin{array}{c}\text { Standard } \\
\text { deviation }\end{array}$ & Min & Max & \multicolumn{2}{c}{$95 \%$ CI } \\
Lower & Upper \\
\hline T1 & 10 & $32.37^{\mathrm{a} \#}$ & 1.91 & 30.24 & 36.22 & 30.99 & 33.74 \\
T2 & 10 & $34.65^{\mathrm{b}}$ & 1.39 & 33.65 & 40.64 & 32.39 & 36.43 \\
T3 & 10 & $39.22^{\mathrm{c}}$ & 1.86 & 37.89 & 40.56 & 36.55 & 42.95 \\
\hline
\end{tabular}

\# Different letters indicate significant differences according to Tukey's HSD test $(P<0.05)$. 

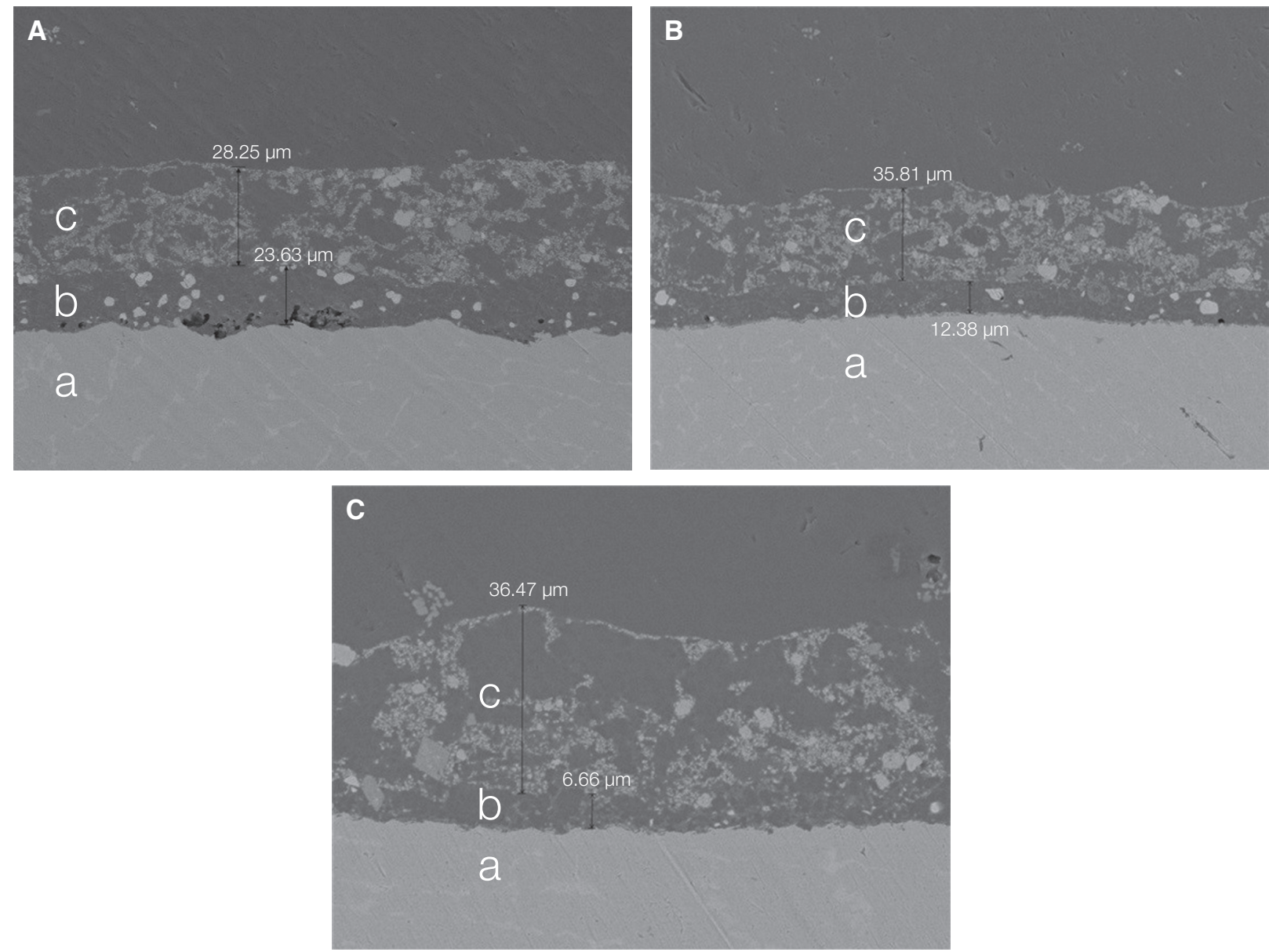

Fig. 2. SEM photographs analysis of metal-ceramic specimen ( $T 1, T 2, T 3$ group). (A) T1 group, (B) T2 group, (C) T3 group. a, metal; b, oxide film; c, porcelain.

가열에 의한 용착으로 결합되는데, 도재를 축성하기 전 에 시행되는 금속의 열처리는 금속 표면에 오염된 유기 물질을 제거하고, 주조과정이나 기공과정에서 생긴 내부 의 stress를 없애 소둔(annealing) 효과를 얻고 금속 내부 의 gas를 방출시켜 도재 제작 시 기포로 인한 균열을 방 지하며, 도재와의 결합에 도움을 주는 산화막을 형성하 기 위한 것으로 산화막의 생성이 과다하거나 부족할 경 우에는 세라믹과 금속의 결합계면에서의 적절한 결합력 의 발휘를 기대 할 수 없다. ${ }^{14,15}$

일반적으로 금속에 생성되는 산화막은 내부산화와 외 부산화 그리고 온도 상승에 따라 주위의 산소와 높은 친 화력을 나타내는 합금 원소의 선택산화에 의한 결과이 며, 사전 열처리 방법에 따라 그 생성 정도가 달라진다.

본 실험은 베릴륨이 함유되지 않은 금속-도재용 $(\mathrm{Ni}-$ $\mathrm{Cr}$ )합금 산화처리 시 도재로 안에 티타늄을 화학적 촉매 로 이용하여 산화막을 억제하고, 금속 표면에 형성될 불
순물을 제어하여 도재의 결합력을 증진시켜 줄 수 있는 가능성을 분석하고자 하였다.

금속-도재간의 결합강도는 3점 굴곡시험을 사용하였 는데 이는 반복적 재현이 가능하며 정량화되어 있고 시 편제작과 실험과정이 용이할 뿐만 아니라 도재 층의 두 께와 금속의 두께가 임상적으로 타당성이 있기 때문이 다. ${ }^{16}$

이러한 3점 굴곡시험은 도재-금속 결합강도 측정에 널 리 사용되고 있는 방법으로 ISO 9693에서 국제 규격으 로 제시하고 있는 방법이다. 3점 굴곡시험에서 시편은 도 재의 두께가 얇을 경우 도재층 내부의 파절이 일어날 수 있으며 이때 측정되는 하중은 결합강도가 아니라 도재의 인장 강도가 측정되는 것이므로 금속과 도재의 두께 비 율이 1:2 이상이 되어야 한다. ISO 결합강도는 금속과 세 라믹의 조합, 열팽창 계수 및 결합재의 사용 유무에 따라 달라지기 때문에 결과 해석에 주의가 필요하다. ${ }^{17}$ 
일반적으로 금속 도재관의 결합력을 평가하기 위하여 실험군을 제작하여 3점 굽힘 시험을 하면 판 모양의 시험 시편 중앙부에 불투명도재를 축성, 소성한 것을 반대 측 에서 가압한 실험한 결과 용착 면 끝부분에서 먼저 박리 되는 양상을 나타낸다.

본 실험의 파절양상을 분석한 결과, $\mathrm{T} 3$ 군이 $\mathrm{T} 2$ 군과 $\mathrm{T} 1$ 군 보다 많은 양의 도재가 금속면에 남아 있었고, 주사현 미경 관찰에서도 T3군이 긴밀하게 결합되어 있는 점으로 입증할 수 있다.

$\mathrm{T} 2$ 군 역시 $\mathrm{T} 1$ 군 보다 높은 결합강도 값이 나온 결과를 살펴보면, T1군은 금속하부구조물에 부착된 불투명도재 가 소성 후 박리(debonding) 되거나 깨짐 현상이 발생되 었지만, $\mathrm{T} 2$ 군은 금속면에 어느 정도 도재가 남아 있었다. 이와 같은 결과는, 베릴륨이 첨가되지 않은 금속에서 빈번 하게 발생되는 과도한 산화막은 결합력을 감소시키는 요 인으로 선행의 논문과도 일치 하였고, ${ }^{18}$ 하부구조물로 사 용한 합금을 열처리 하면 산소와의 친화력이 크고 확산속 도가 빠른 원소들이 표면으로 이동하여 산화물을 형성하 게 되는데, 금속표면 산화막에서 산소농도가 급격하게 증 가하여 금속표면에 산화물이 형성된 결과로 판단된다.

베릴륨이 함유되지 않은 금속-도재용 $(\mathrm{Ni}-\mathrm{Cr})$ 합금 산화 처리 시 도재로 안에 티타늄을 화학적 촉매로 이용한 금 속-도재 계면의 파절을 육안으로 관찰한 결과, 시편 모두 유사하게 하중이 가해진 하방으로 수직적인 도재의 파 절 양상이 관찰되었고, 도재와 금속 간의 파절 양상은 도 재와 도재 사이에서 파절이 발생하는 응집실패(cohesive failure)와 도재와 코핑 사이에 파절이 나타나는 부착실 패(adhesive failure)가 함께 관찰된 혼합실패 양상이 관 찰되었다.

$\mathrm{T} 1$ 군은 비귀금속합금과 도재 간의 파절양상에서 금속 계면에 도재가 일부 남아 있는 혼합실패 양상으로 나타 나고 있지만, 부착실패의 양상이 두드러졌다. 이 결과는 비귀금속합금과 도재 간의 파절양상은 부착파절 양상이 보인다는 선행연구 와는 일치하였다. ${ }^{19} \mathrm{~T} 2, \mathrm{~T} 3$ 군의 경우 는 응집실패 의 양상이 두드러지는 혼합실패 양상이 나 타나고 있었다.

이는 티타늄 파우더가 화학적 촉매로 이용한 실험군의 비귀금속합금과 도재 간의 결합력이 더 우수함을 보여주 는 결과이며, 주사전자현미경 상으로 관찰 된 티타늄 파 우더를 화학적 촉매로 이용된 T2, T3군의 경우, 도재 사 이에 파절이 일어나 도재가 금속의 표면에 많이 부착되 어 잔존하는 것으로 나타났고, 티타늄 파우더의 양이 더
첨가 된 $\mathrm{T} 3$ 군의 경우, 조금 더 많은 도재의 접착을 보이 는 것으로 실험결과 나타났다.

금속-도재간의 화학적 결합은 금속표면에 형성된 산화 물이 도재 내로 확산되어 도재 내 산화물과 공유결합이 나 이온결합을 함으로 이루어진다. 적절한 산화막을 가 지는 도재용 금속의 계면은 산화막이 너무 두껍거나 얇 은 계면보다 접착실패에 대한 저항성이 더 큰 것으로 알 려져 있다. ${ }^{20}$ 비 귀금속은 주성분들이 쉽게 산화되어 과도 한 산화막이 형성 될 수 있는데 산화막 두께조절은 결합 강도를 확보 하는데 중요하다. ${ }^{21}$

티타늄 또한 $800^{\circ} \mathrm{C}$ 이상의 온도에서 산소, 질소 등과 반응하여 비교적 두껍고 쉽게 분리되는 티타늄 산화막을 형성 한다. ${ }^{22}$

티타늄 도재 소성과 주조 시 산화가 일어나며, $\alpha$-case 라 불리는 두꺼운 산화층은 연성과 피로 저항성을 감소 시켜 티타늄으로부터 도재의 파절을 야기 시키므로 티타 늄-도재의 결합력을 저하시킨다고 발표 되고 있다. ${ }^{23}$

금속과 도재 간의 결합강도를 결정하는 기계적 결합, 분자 간 인력, 산화물에 의한 화학적 결합, 열팽창 계수 등이 원인으로 들 수 있으나, 티타늄-도재 수복물의 낮은 결합강도는 Adachi 등 ${ }^{24}$ 은 티타늄과 도재 간의 낮은 결합 강도는 티타늄에 대한 산화막의 부착이 불안정하기 때문 이며, 이러한 불안정한 산화막은 도재 소성 중에 생성되 고 결합강도를 저하시킨다고 하였다.

티타늄은 공기 중 표면에 산화막을 형성하기도 하지만 고온으로 가열되면 $\mathrm{TiO}, \mathrm{Ti}_{2} \mathrm{O}_{3}, \mathrm{TiO}_{2}$ 의 층상 산화물피막 을 형성, 표면처리 되어 내식성을 유지하는 성질을 갖고 있어 화학적 촉매로 이용할 경우, 산화처리 시 첨가된 티 타늄이 산소와 결합하여 산화물피막 형성이 금속계면에 형성될 산화막을 억제하고, 불순물을 제어하여 일률적인 막을 형성 한 것 사료된다.

티타늄을 이용한 합금의 개발이 일시적으로 이뤄졌지 만. 결합강도가 떨어지고 열팽창계수조절이 필요한 도재 소재의 한계성으로 인한 색조 및 주조성의 문제가 나타 나 최근에는 연구되고 있지 않고 있다. 티타늄은 생체 친 화적으로 치과산업에서는 매식의치(implant)분야인 뼈와 매식되는 금속과의 골 유착을 위한 개발은 활발하게 연 구되고 생산되고 있으며, 타 분야에서도 활발하게 연구 되고 있다. 또한 환경 친화적인 촉매제로 적용되고 있는 아주 뛰어난 소재로써 4 차 산업의 변화에 지대한 영향을 미칠 것으로 사료된다.

금속과 도재 간의 결합강도의 결합력 향상을 방법의 
연구가 다양하게 연구되고 있지만, 생체 친화적이나 티 타늄합금과 도재의 결합문제로 인한 연구의 발표는 미진 하므로 연구가 계속될 필요성이 있다고 생각된다.

본 연구를 종합적으로 분석한 결과, 산화처리 시 도재 로 안에 티타늄 파우더를 화학적 촉매로 이용한 결합강 도 실험결과는 $10 \mathrm{~g}$ 넣은 것 보다 $20 \mathrm{~g}$ 넣은 $\mathrm{T} 3$ 군이 $\mathrm{T} 2$ 군 및 T1군 보다 높게 나타났으며, 통계학적으로 유의차가 있는 것으로 분석되었다 $(P<0.05)$.

대조군(T1군)의 금속과 산화물 사이에서 파절이 일어 나는 접착성(adhesive) 결합실패는 두꺼운 산화층이 형성 된 결과라 사료되며, T2, T3군은 결합강도를 높이기 위 하여 산화처리 시 티타늄파우더를 화학적 촉매로 사용한 결과, 산화막을 억제하고, 금속 표면에 형성될 불순물을 제어하며, 얇고 일률적인 막을 형성한 것은 도재의 결합 력을 증진시켜 줄 수 있다는 가능성을 보여 주었다.

\section{결론}

본 논문에서는 베릴륨이 함유되지 않은 금속-도재용 (Ni-Cr)합금 산화처리 시 티타늄 파우더를 첨가하여(T1, $\mathrm{T} 2, \mathrm{~T} 3)$ 소성한 후 결합강도를 측정하고 산화막 두께를 비교한 결과 다음과 같은 결론을 얻었다.

1. 대조군 $\mathrm{T} 1$ 군의 결합강도는 $32.37 \pm 1.91 \mathrm{MPa}$, 산화 막 두께는 $23.63 \mu \mathrm{m}$ 으로 나타났다.

2. 실험군 $\mathrm{T} 2$ 군의 결합강도는 $34.65 \pm 1.39 \mathrm{MPa}$, 산화 막 두께는 $12.38 \mu \mathrm{m}$ 으로 나타났다.

3. 실험군 $\mathrm{T} 3$ 군의 결합강도는 $39.22 \pm 3.41 \mathrm{MPa}$, 산화 막 두께는 $6.66 \mu \mathrm{m}$ 으로 가장 높게 나타났다. 티타 늄 파우더를 화학적 촉매로 이용할 때 산화막을 억 제하고, 도재의 결합력을 증진시켜 줄 수 있는 가능 성을 확인하고 사후검정(Tukey Honestly Significant Difference test)에서도 유의차가 있는 것으로 분석 되었다 $(P<0.05)$.

\section{Acknowledgements}

본 논문은 2017년도 신한대학교 학술연구비 지원으로 연구되었음.

\section{References}

1. Wataha JC, Messer RL. Casting alloys. Dent Clin North Am 2004;48:499-512.
2. McCabe JF, Walls AWG. Applied dental materials. 7th ed. London; Mass Publishing Co.; 1994. p.71-8.

3. Oshida Y, Fung LW, Isikbay SC. Titanium-porcelain system. Part II: bond strength of fired porcelain on nitrided pure titanium. Biomed Mater Eng 1997;7: 13-34.

4. Cascone PJ, Massimo M, Tuccillo JJ. Theoretical interfacial reactions responsible for bonding in porcelain-to-metal systems. Part II-Oxidation of alloys. J Dent Res 1978;57:872.

5. Sakaguchi R, Powers J. Resin composite restorative materials. Craig's restorative dental materials. 12th ed. St. Lousis; Mosby Elsevier; 2006. p. 189-212.

6. Morris HF. Properties of cobalt-chromium metal ceramic alloys after heat treatment. J Prosthet Dent 1990;63:426-33.

7. Pierce LH, Goodkind RJ. A status report of possible risks of base metal alloys and their components. J Prosthet Dent 1989;62:234-8.

8. Magnusson B, Bergman M, Bergman B, Söremark R. Nickel allergy and nickel-containing dental alloys. Scand J Dent Res 1982;90:163-7.

9. Wang RR, Welsch GE, Monteriro O. Silicon nitride coating on titanium to enable titanium-ceramic bonding. J Biomed Mater Res 1999;46:262-70.

10. Walter M, Reppel PD, Böning K, Freesmeyers WB. Six-year follow-up of titanium and high-gold porcelain-fused-to metal fixed partial dentures. J Oral Rehabil 1999;26:91-6.

11. Kaus T, Pröbster L, Weber H. Clinical follow-up study of ceramic veneered titanium restorations three-year results. Int J Prosthodont 1996;9:9-15.

12. Sandrock G, Gross K, Thomas G. Effect of Ticatalyst content on the reversible hydrogen storage properties of the sodium alanates. J Alloy Compd 2002;339:299-308.

13. Matković T, Slokar L, Matković P. Structure and properties of biomedical Co-Cr-Ti alloys. J Alloy Compd 2006;407:294-8.

14. Dent RJ, Preston JD, Moffa JP, Caputo A. Effect of oxidation on ceramometal bond strength. J Prosthet Dent 1982;47:59-62.

15. O’brien WJ, Seluk LW, Fan PL, Saunders DN. Classification of porcelain enamel interfacial fractures. J Dent Res 1976;55:506. 
16. Lenz J, Schwarz S, Schwickerath H, Sperner F, Schäfer A. Bond strength of metal-ceramic systems in three-point flexure bond test. J Appl Biomater. 1995;6:55-64.

17. Barghi N, Lorenzana RE. Optimum thickness of opaque and body porcelain. J Prosthet Dent 1982; 48:429-31.

18. DeHoff PH, Anusavice KJ, Hathcock PW. An evaluation of the four point flexural test for metalceramic bond strength. J Dent Res 1982;61:1066-9.

19. Choi BK, Han JS, Yang JH, Lee JB, Kim SH. Shear bond strength of veneering porcelain to zirconia and metal cores. J Adv Prosthodont 2009;1:129-35.

20. Kelly JR, Rose TC. Nonprecious alloys for use in fixed prosthodontics: a literature review. J Prosthet
Dent 1983;49:363-70.

21. Bondioli IR, Bottino MA. Evaluation of shear bond strength at the interface of two porcelains and pure titanium injected into the casting mold at three different temperatures. J Prosthet Dent 2004; 91:541-7.

22. Shell JS, Nielsen JP. Study of the bond between gold alloys and porcelain. J Dent Res 1962;41:142437.

23. Okabe T, Hero $\mathrm{H}$, The use of titanium in dentistry. Cell Mater 1995;5:211-30.

24. Adachi M, Mackert JR Jr, Parry EE, Fairhurst CW. Oxide adherence and porcelain bonding to titanium and Ti6Al-4V alloy. J Dent Res 1990;69:1230-5. 


\section{티타늄 파우더가 금속의 열처리 시 결합강도에 미치는 영향}

\section{김사학 ${ }^{1}$, 김욱태 ${ }^{2 *}$}

${ }^{1}$ 경동대학교 치기공학과, ${ }^{2}$ 신한대학교 보건과학대학 치기공학과

목적: 본 연구는 베릴륨이 함유되지 않은 금속-도재용(Ni-Cr)합금 산화처리 시 도재로 안에 티타늄 파우더를 화학적 촉 매로 이용하여 산화막을 억제하고, 금속 표면에 형성될 불순물을 제어하여 도재의 결합력을 증진시켜 줄 수 있는 가능성 을 분석 하고자 하였다.

연구 재료 및 방법: 베릴륨이 함유되지 않은 금속-도재용 $(\mathrm{Ni}-\mathrm{Cr})$ 합금 산화처리 시 도재로 안에 티타늄을 화학적 촉매로 이용하였다. 티타늄 파우더를 화학적 촉매로 사용하지 않은 T1군을 대조군으로 하고, $10 \mathrm{~g}, 20 \mathrm{~g}$ 티타늄 파우더를 사용 한 시편을 T2, T3군으로 분류하여 전단결합강도와 계면특성 관찰을 위하여 제작 하였다. 일원배치 분산분석(one-way ANOVA)은 그룹의 차이를 검사하기 위해서 시행하였고 사후 검정(Tukey Honestly Significant Difference test)은 그룹 간의 통계적 분석을 위하여 수행되었다.

결과: 티타늄 파우더를 화학적 촉매로 사용 한 T3군의 3점 굽힘 결합강도와 산화막 두께를 측정한 결과, $39.22 \pm 3.4$ $\mathrm{MPa}$ 와 $6.66 \mu \mathrm{m}$ 로 가장 높고, 얇게 나타났으며, T2군은 $34.65 \pm 1.39 \mathrm{MPa}$ 과 $13.22 \mu \mathrm{m}$, 티타늄 화학적 촉매로 사용하지 않은 대조군 $\mathrm{T} 1$ 군은 $32.37 \pm 1.91 \mathrm{MPa}$ 과 $22.22 \mu \mathrm{m}$ 순으로 나타났다.

결론: 시편들의 결합강도를 통계 분석한 결과, 티타늄 파우더를 화학적 촉매로 사용한 실험 $\mathrm{T} 3, \mathrm{~T} 2$ 군의 결합력이 높게 나타났고, 산화막 두께 역시 대조군 T1군 보다 얇게 나타나 것으로 결합력 증진에 영향을 줄 수 있음이 관찰 되었다.

(구강회복응용과학지 2017;33(2):71-9)

주요어: 베릴륨; 티타늄; 화학적 촉매; 산화막; 결합강도

*교신저자: 김욱태

(11644)경기도 의정부시 호암로 95, 신한대학교 보건과학대학 치기공학과

Tel: 031-870-3427 | Fax: 031-870-3429 | E-mail: wrdeul@hanmail.net

접수일: 2017년 1월 14일 | 수정일: 2017년 3월 19일 | 채택일: 2017년 4월 10일 